\title{
Relationships between Self-esteem and Factors Known to Affect College Attendance
}

\author{
Adam A. Torres: McNair Scholar \\ Dr. Mary Pritchard: Mentor \\ Department of Psychology
}

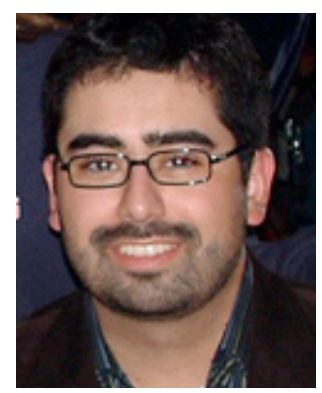

\begin{abstract}
There are many factors impacting student's decisions to attend college. Researchers investigated selfesteem, perceived academic abilities, and intended college attendance in a group of high school seniors involved in a program aimed at assisting them get into college. Participants were 83 senior high school students (males $=28$, females $=55$ ) from various high schools in Idaho. Many students come from low socioeconomic backgrounds and were Caucasian (Caucasian $=40$, Latino $=28$, Asian $=6$, African American $=2$, and other $=6$ ). Participants were asked 39 questions concerning intended college attendance, self-esteem, perceived academic abilities, and other factors that influenced their decision to attend college. Significant correlations were found between self-esteem and perceived academic abilities.
\end{abstract}

\section{Introduction}

The U.S. Department of Health and Human Services (1997) conducted multiple surveys between 1967 and 1994 that revealed a drop in the income to poverty ratio scale from 0.74 to 0.66 , suggesting that families are getting poorer and are in need of more help if children are planning to attend college in the future. Understanding the adversity that low-income families face, it is relatively easy to see the difficulties that students from these families endure when considering post-secondary education. The financial portion of school is only part of the equation. Because of the growing number of families classified as low-income, programs helping low income youth overcome adversity are becoming increasingly important.

TRiO is an educational opportunity for low-income and disabled Americans and is present at more 1,000 colleges, universities, community colleges, and agencies in America. Their commitment is to provide educational opportunities for all Americans regardless of race, ethnic background or economic circumstance. Along with this commitment, Congress established a series of programs to help low-income Americans enter college, graduate and move on to participate more fully in American society. While student financial aid programs help students overcome financial barriers to higher education, TRiO programs help students overcome class, social and cultural barriers to higher education (http:// www.coenet.us).

As mandated by Congress, two-thirds of the students served by TRiO must come from families with incomes under $\$ 28,000$, where neither parent graduated from college. More than 2,700 TRiO programs currently serve nearly 866,000 low-income American students in sixth through twelfth grade. According to TRiO, $37 \%$ of the students are White, $35 \%$ are African-American, $19 \%$ are Hispanics, $4 \%$ are Native Americans, $4 \%$ are Asian-Americans, and 1\% are listed as "Other," including multiracial students. TRiO programs serve twenty-two thousand students with disabilities and more than 25,000 U.S. veterans (http://www.coenet.us).

Students in TRiO's Upward Bound program are said to be four times more likely to earn an undergraduate degree than are those students from similar backgrounds who did not participate in TRiO. Nearly 20 percent of all Black and Hispanic freshmen entering college in 1981 received assistance through the TRiO Talent Search or Educational Opportunity Center programs, and students in TRiO's Student Support Services program are more than twice as likely to remain in college than are those students from similar backgrounds not enrolled in the program (http://www.coenet.us). Considering students in TRiO programs come from underrepresented groups, either in ethnicity or socioeconomic status, and the low percentage of these groups in higher education (Sallie Mae Foundation, 2006), the effect of TRiO in diversifying higher education has been immense. Yet, there are still students who choose not to pursue postsecondary education despite having resources provided by $\mathrm{TRiO}$, which poses the question of what additional factors impact student's intention of attending college. 
There are many factors that influence student's decisions to attend college, such as finances, peer influence, and self-esteem (Coleman, 1965; Garfinkel, 2003). Due to the similarities between students that constitute TRiO programs, such as low-income status, it is important to examine some of these factors, such as neighborhood quality, which was related to self-perceived academic abilities, and in turn, related to school effort (Ceballo, McLoyd, \& Toyokawa, 2004). In addition to the previous study, Gerardi (2005) found academic self-concept (perceived academic abilities) to significantly predict academic performance in low-income students. Furthermore, academic self-concept was shown to better predict learning persistence by other studies (House, 1992; Li-Fang, 2006).

Furthermore, Rosenberg (1989) has shown there to be a relationship between socioeconomic status and self-esteem. Contrary to these findings, some studies have found no relationship between socioeconomic status and scholastic self-perception (Schmitz, 2006) or socioeconomic status and selfesteem (Lever, Pinol, \& Uralde, 2005). In addition to socioeconomic status influencing student's selfesteem and perceived academic abilities, a relationship between self-esteem and academic success has developed in the literature. Some studies have found self-esteem to be positively correlated with academic achievement and negatively correlated with counterproductive behavior, like aggression and delinquency (Alves-Martins, Peixoto, Gouveia-Pereira, Amaral, \& Pedro, 2002; Donnellan, Trzesniewski, Robins, Moffitt, \& Caspi, 2005). In addition, another study found a positive relationship between academic achievement and self-esteem (El-Anzi, 2005) and also, self-control was found to lead to higher self-esteem and higher grades (Tangney, 2004). Yet contrary to the previous studies, Sirin (2004) found self-esteem to have no relationship to academic performance. Because self-esteem has been found to play a role in academic performance, we found it necessary to incorporate a shortened version of the Rosenberg SelfEsteem Scale (Rosenberg, 1989) in our study.

It is in our interest to understand how self-esteem affects adolescents in their pre-college schooling to better help them adjust and become better prepared for higher education. Addressing the problem earlier or during a time when children are seeking the help of others, and doing what we can to encourage and increase their self-esteem would be beneficial to them in many ways. Thus, our study examines how selfesteem relates to intended college attendance. More specifically, we hypothesize that intended college attendance will decrease when self-esteem is low and conversely, intended college attendance will increase as self-esteem increases. In addition to questions about self-esteem, we also asked about the student's perception of their math skills, writing skills, and grades, family support or pressure, helpfulness of career information and college visits, and level of involvement in TRiO related activities. Researchers felt it necessary to ask exploratory questions due to the relationship between self-esteem and academic achievement. It is well-established that variables such as perception of math skills relate to intended college attendance, but we wanted to examine how other variables known to relate to college attendance relate to self-esteem. Also, these questions have more practical implications for TRiO and are a way to understand student's perception of common activities and other pressures surrounding college. Researchers hypothesize a positive correlation between self-esteem, greater perceived academic abilities, family support, and helpfulness of career information and college visits.

\section{Method}

\section{Participants}

Participants were 83 senior high school students (males $=28$, females $=55$ ) from various urban high schools in Idaho. The majority of the students were Caucasian (Caucasian $=40$, Latino $=28$, Asian $=$ 6 , African American $=2$, and other $=6$ ). All students were involved in a college preparation program designed for low income, underrepresented college students, TRiO. The vast majority of students reported that they planned on attending college. In fact, only seven of the 83 students reported not planning on attending college. Prior to any data collection, this study was approved by the Institutional Review Board.

\section{Materials}

Students were asked whether they planned on attending college. In addition, self-esteem was measured by an abridged 5-item version of the Rosenberg Self-Esteem Scale (1989; alpha = .87). Although an abridged version is not ideal, due to lack of time available with students we had to cut it down. In addition to self-esteem, researchers asked questions concerning student's perception of their math and writing skills, grades, family support or pressure, helpfulness of career information and college visits, and 
level of involvement in TRiO related activities. A four-point Likert scale was used, ranging from strongly disagree (0) to strongly agree (3). In addition to the above items, we collected demographic data.

\section{Procedure}

TRiO staff members were responsible for survey administration. TRiO staff members pulled students out of their classes at different times of the day and interacted with them on a one on one basis. Staff members read to all students prior to the survey a disclaimer stating that if any questions made them feel uncomfortable they did not have to answer it and they had the option to quit the survey. The survey took 10 to 15 minutes to complete. Students completed the survey on scantron sheets.

\section{Results}

To examine the relationship between intendance to attend college directly after high school and self-esteem, we ran an independent samples t-test. Given a small number of students that reported that they did not plan on attending college, it is not surprising that we did not find a significant difference in selfesteem between individuals that planned to attend college $(M=11.65, S D=3.28)$ and those who did not plan to attend college $(M=10.17, S D=2.56), t(81)=1.08$. To further examine the influence of self-esteem on variables related to college attendance, we ran correlations between self-esteem and survey items. As displayed in Table 1, many of the factors known to influence college attendance related to self esteem, including receptiveness to career information, college visits, perceived writing skills, perceived math skills, GPA, family support, family pressure, and participation in TRiO activities.

\section{Discussion}

The goal of this study was to examine associations between those who planned to attend college and those who did not. Some of our hypotheses were confirmed, whereas others were not. Our first hypothesis was that high self-esteem would predict planned college attendance. Previous research has suggested that high self-esteem is related to academic achievement (Alves-Martins et al., 2002; Donnellan et al., 2005). However, it was not found to be significant in the present study, which was likely due to the low number of students who reported they were not planning on attending college after high school. It also may be that we used five questions from the Rosenberg Self-Esteem scale, instead of the full scale due to the time constraints placed on or survey. This possibility should be investigated more because of the strong relation between academic achievement and self-esteem.

There were some interesting correlations between self-esteem and other variables known to relate to college attendance. First, there was a negative correlation between student's perception of how helpful the career information was and self-esteem. It could be that students are discouraged about their future because they do not have a specific interest or know what they would like to do. Also, there was a negative correlation between self-esteem and how students perceived the college visits. That is, those students who have a low self-esteem were likely to have realized that college was not a possibility through college visits. In this case again, they may be discouraged about attending college. It could be that leaving their social support network makes it difficult for them to go to college. Probably the most interesting finding was that those who had lower self-esteem also reported that their math and writing skills were holding them back from attending college. Perhaps these students have anxiety over their abilities in these areas, which could contribute to lower self-esteem. Also, there was a positive correlation between self-esteem and student perception of adequacy of their grades for college; that is, those who had a higher self-esteem also perceived their grades as adequate for college. Perhaps math and writing skills provide a greater source of self-esteem measure than do grades and therefore, a reference point as to whether they ought to attend college.

\section{Limitations}

As with any study, there is room for improvement. First, we were not able to survey the entire population of TRiO students, nor were researchers able to ensure the survey was taken in the same setting for each student. Secondly, we did not have an adequate sample size. A third limitation was that we were surveying high school students that consisted primarily of Caucasian females. Fourth, survey length was an issue in the present study. If it were possible to create a longer survey with multiple questions for each 
variable of interest, the end results may be different. Finally, our sample was composed of high school seniors who are awaiting graduation and basing their perception on what they foresee in the future. The fact that we did not have access to students who graduated and either advanced to college or not, contributed to a major loss of valuable data that undoubtedly would have influenced our results. Although only seven of the 83 students surveyed reported not planning on attending college after high school, the number could be more than seven that actually do not attend college when it comes time to enroll. Whether they plan on attending college or not is only what they plan on doing in the future and so the variables affecting whether that actually happens might not be measured accurately. In addition, the results in this study are a survey of potential reasons for these students not to attend college, whereas if we had access to graduated students, they could inform us better about which variables actually contributed to them not advancing to college in retrospect.

\section{Conclusion}

Our study examined the influence of self-esteem on intended college attendance, as well as the relation between self-esteem and several variables known to predict college attendance. Future research should examine why self-esteem is negatively correlated with college visits and career information. This could help guidance counselors and staff involved in planning college visits change aspects of college visits and career information in order to make them more appealing to students with lower self-esteem or help students not to be discouraged if they do not have a specific academic plan. Another interesting correlation found in our survey was that lower self-esteem individuals were more likely to report their math and writing skills were holding them back from attending college. Research should be done to discover if students are dealing with anxiety or are actually lacking in their math and writing skills and how each affects self-esteem by utilizing standardized test scores and comparing them to their perceived abilities. Regardless, to enhance college enrollment, guidance counselors and staff involved in college recruiting programs need to address issues such as anxiety over math and/or writing skills and self-esteem.

\section{Tables}

Table 1. Correlations between self-esteem and various survey questions.

Survey Question

The career information did not help me in any way.

The college visits made me realize that college was not a possibility for me.

My writing skills are holding me back from going to college.

My math skills are holding me back from attending college.

My grades are adequate for college.

My family is supportive of me going to college.

My family is pressuring me not to attend college.

How many hours per month do you participate in TRiO activities?

Note: ${ }^{*} \mathrm{p}<.05,{ }^{* *} \mathrm{p}<.01,{ }^{* * *} \mathrm{p}<.001$ 


\section{Acknowledgments}

I would like to acknowledge Dr. Mary Pritchard for her help and guidance through the research process and for always having an open door. I would also like to thank David Hall, Helen Barnes, and Greg Martinez, for providing such a great opportunity and creating a network of people that truly helped me succeed.

\section{References}

Alves-Martins, M., Peixoto, F., Gouveia-Pereira, M., Amaral, V., \& Pedro, I. (2002). Self-esteem and academic achievement among adolescents. Educational Psychology, 22(1), 51-62.

Ceballo, R., McLoyd, V. C., \& Toyokawa, T. (2004). The influence of neighborhood quality on adolescents' educational values and school effort. Journal of Adolescent Research, 19, 716-739.

Coleman, J. (1965). Family and peer influences in college plans of high school students. Sociology of Education, 38, 112-126.

Continuing America's commitment to low income and disabled students. (2006). What is TRiO? Retrieved February 16, 2006, from http://www.coenet.us

Donnellan, M. B., Trzesniewski, K. H., Robins, R. W., Moffitt, T. E., \& Caspi, A. (2005). Low self-esteem is related to aggression, antisocial behavior and delinquency. Psychological Science, 16, 328-335.

El-Anzi, F. O. (2005). Academic achievement and its relationship with anxiety, self-esteem, optimism, and pessimism in Kuwaiti students. Social Behavior and Personality, 33, 95-104.

Garfinkel, I., Huang, C., \& Han, W. (2003). The importance of family structure and family income on family's educational expenditure and children's college attendance. Journal of Family Issues, 24, 768-771.

Gerardi, S. (2005). Self-concept of ability as predictor of academic success among urban technical college students. Social Science Journal, 42, 295-300.

House, D. J. (1992). The relationship between academic self-concept, achievement-related expectancies, and college attrition. Journal of College Student Development, 33, 5-10.

Lever, J. P., Pinol, N. L., \& Uralde, J. H. (2005). Poverty, psychological resources and subjective wellbeing. Social Indicators Research, 73, 375-409.

Li-Fang, Z. (2006). A research on relations among the academic self-concept, achievement goal orientation and learning persistence of college students. Chinese Journal of Clinical Psychology, 14, 192-193.

Rosenberg, M. (1989). Society and the adolescent self-image. (Revised ed.). Middletown, CT: Wesleyan University

Sallie Mae: College Answer. (2006). The planning for college destination. Retrieved February 21, 2006, from www.collegeanswer.com

Schmitz, M. F. (2006). Influence of social and family contexts on self-esteem of Latino youth. Hispanic Journal of Behavioral Sciences, 28, 516-531.

Sirin, S. R. (2004). Exploring school engagement of middle-class African American adolescents. Youth \& Society, 35, 323-340.

Tangney, J. P. (2004). High self-control predicts good adjustment, less pathology, better grades, and interpersonal success. Journal of Personality, 72, 271-322.

U.S. Department of Health and Human Services. (1997). Trends in the well-being of America's children \& youth. Retrieved February 17, 2006, from http://aspe.os.dhhs.gov/hsp/97trends/Es1-2.htm 